The actual process of building a log cabin in the woods, particularly in such a remote location, is fascinating. The cabin is built in several steps, over numerous months, using hand tools, chainsaws, and, occasionally, some friends.

There are a few drawbacks from the enjoyment of this book though, especially without having read the first three. The first is that in this book there are a number of interesting stories that are alluded to but not told in detail because they've been recorded in the previous books. The second is that the letters are all to Nick and because it does not include the letters written from him, it feels a bit like being in the same room with someone on the phone - you hear half the conversation and although you get the gist of the whole, you feel the missing of the other half. The third and most perplexing is the lack of description of the characters or their relationship with each other. The reason this is perplexing is because the author herself describes this criticism received from a book reviewer - and then simply passes it off with "The trouble is, I live with the people I write about. Experience has shown that no matter how innocuous a portrait I paint, the subject will find something about which he or she is unhappy." While I am sure this could be true, the book would earn a wider audience if it were not written for those people alone.

DAWN BURNETT

Jacques Whitford Limited, 1 Union Street, Elmira, Ontario N3B 3J9

\title{
Natural Grace: The Charm, Wonder, \& Lessons of Pacific Northwest Animals \& Plants
}

By William Dietrich. 2003. University of Washington Press, 1326 Fifth Avenue, Suite 555, Seattle, Washington 981012604 USA. 236 pages. U.S.\$19.95

Natural Grace is a contemporary example of the medieval book of beasts called a bestiary. Bestiaries were very popular during the Medieval Period, and focused on the life of nature as a model or paradigm for human behavior. These books were not scientific in the contemporary sense of the term, but instead combined religious and moral teaching with a close observation of nature, zoological commentaries, and fabulous and fictitious creatures. Rather than being studied in and of itself, nature was considered symbolic of both the virtue and moral life of human beings. While Deitrich's work certainly provides the reader with a more sophisticated scientific understanding of nature, the subtitle of the book betrays its "bestiary" lineage as the reader is invited to appreciate the charm, wonder, and lessons of a variety of creatures and natural phenomena.

This collection of essays is adapted from William Dietrich's popular articles in the Seattle Times' Northwest Magazine. The author divides his work among four themes: (1) the common and ubiquitous creatures that we often take for granted, (2) the itty-bitty world that ranges from soil to spiders, (3) the rhythmic, clockwork world of tectonics and tides, and finally, (4) the iconic symbols of the Pacific Northwest including, among others, the bald eagle and the killer whale or orca.

Dietrich is gifted with the contemplative eye. Follow his gaze and you will enter a world of delight and amazement. We live side by side with other creatures and are immersed within the workings of nature. But often, we are oblivious to the ways of our environs, so intent and fascinated are we with our own creations and fabrications. Dietrich pries apart our fabricated world and invites us to direct our gaze out beyond the confines of culture. He calls us to a long loving gaze on the other of nature.
This contemplative gaze is a virtue that strengthens with time and practice. Dietrich is a patient and humorous guide, gently leading the reader to grow in knowledge of the natural world; knowledge, not simply of the biological or physical facts, but of the beauty, significance, and yes, even mystery inherent in the subject of our gaze. Of special interest is the manner by which the author weaves together culture and nature. Whether it be the forces of nature that define the boundaries of human culture and provide the myriad free ecological services that allow us our cities and farms, or the manner in which particular species have become embedded in our folk and cultural lore, the reader is left with the knowledge that we are dependent on the "others" of nature far beyond our physical survival.

Human ignorance instills fear, and fear breeds violence and destruction. Natural Grace sets a contrary path. Knowledge of the other, of nature, can lead to intimacy, and intimacy can be the foundation of love. Love, in turn, leads to mutuality, care, and concern for the other. Dietrich's melodious writing can indeed lead one to greater love of nature and hopefully, action on behalf of nature.

This book is a lovely blend of nature and culture, of scientific vulgarization and social lore. You will learn much about the natural history of the Pacific Northwest. As well, I think, you will learn about how we (and maybe you yourself) relate to the natural world, and how that relationship has changed with time, and how it may or must change in the future.

Given Dietrich's place of habitation (Seattle), this book focuses on the State of Washington, with excursions south to Oregon and north to British Columbia. So, if you call the Pacific Northwest your home, you will learn much about your "neighbours." However, regardless of one's geography, Dietrich's work is more a work of perspective, rather than of content. His actors live and work in the Pacific Northwest, but the perspective shared is universal. No matter where you 
live, the long, loving, contemplative gaze on the real is always a possibility.

The $12^{\text {th }}$ century Cistercian monk, Saint Bernard of Clairvaux, once said; "I have discovered that you will find far more in the forests than in books; trees and stones will teach you that which you cannot learn from any master." Turn a discerning eye to the crea- tures and processes that surround you and you will enter a world of marvel and beauty. Let Natural Grace be your companion and guide.

JOHN MCCARTHY, S.J.

St. Mark's College, University of British Columbia, 5935 Iona Drive, Vancouver, British Columbia V6T 1J7 Canada

\section{Tales from the Underground: A Natural History of Subterranean Life}

By David W. Wolfe. 2001. Perseus Publishing, 5500 Central Avenue, Boulder, Colorado 80301 USA. 221 pages. $\$ 27.50$

Tales from the Underground is a MUST read for any naturalist interested in what's happening under our feet. The book is engaging, well-written, and filled with information that is truly awesome.

In the introduction, author David Wolfe, Associate Professor of Plant Ecology at Cornell University, invites his "subterranean-impaired" readers to use their imaginations and join him on a dive trip into a mysterious world scientists are only just beginning to understand. Wolfe launches the journey with a description of the various soil "profiles", also known as layers or horizons, and the organisms that inhabit them. Some of the life forms I had never heard of; others I had never thought about in the way Wolfe describes them.

Take plants, for example. Wolfe starts by praising their display of foliage aboveground. He then points out that plants are unique because they simultaneously inhabit both the surface and sub-surface realms. $\mathrm{He}$ calls them the "great mediators between the two realms", and explains their functions both above and below the ground, with a focus on their buried other half: roots.

In Part I of the book, "Ancient Life", Wolfe covers a lot of ground. He discusses theories of the origin of life, the basic elements necessary for the evolution of life, Earth's advantage as a life-generating planet, and speculation pointing to the subterranean realm as the place where life began. He also introduces "extremophiles", creatures that live in severe conditions thousands of feet underground, where pressure and temperatures are extraordinarily high, and where there is neither light nor oxygen - the postulated setting for the beginning of life.

Wolfe also describes Carl Woese's discovery of the amazing genetic diversity of these extremophiles, and discusses how that discovery changed the universal tree of life. Originally composed of bacteria, plants, fungi, animals and protozoa, the tree of life now has only three branches - bacteria, archaea (the extremophiles) and eukarya (with plants and animals as two small twigs). It's a fascinating and humbling picture.

In Part II, "Life Support for Planet Earth", Wolfe dedicates an entire chapter to Charles Darwin and the lasting influence of the renowned scientist's meticulous and painstaking work. Wolfe also portrays certain inconspicuous subterranean creatures and the important roles they play in cycling essential elements and facilitating the flow of energy - processes that sustain life on this planet. He also discusses the dual roles played by soil with respect to plant and animal diseases; some soil microbes cause diseases, while others provide powerful antidotes.

The third part of the book, "The Human Factor", describes the enormous footprint of Homo sapiens on the planet. Wolfe tells the sobering, appalling story of human activities and their devastating impacts on wildlife such as prairie dogs, black-footed ferrets, and burrowing owls, and on soil integrity in general. Descriptions of soil erosion and the 1930s dust bowl crisis are particularly gripping.

Yet despite the doom and gloom, Wolfe ends on an optimistic note. The very last sentence of the book reads, "It is my hope that as more of us become aware of the life beneath our feet, and its relevance to our well-being, we will be inclined to work together to maintain the biological integrity of the underground, and preserve some of what we find there for future generations" - words we have heard before in one form or another, but good to see repeated in this context.

Tales from the Underground is David Wolfe's first book, and I hope it isn't his last. He has a pleasant and easy-to-read writing style, and manages to convey scientific concepts so that even a non-scientific type like me can understand. Tales from the Underground has found a permanent place on my bookshelves.

\section{R. SANDER-REGIER}

RR5 Shawville, Quebec J0X 2Y0 Canada 